\title{
Assessing Tree Drought Resistance and Climate-Growth Relationships under Different Tree Age Classes in a Pinus nigra Arn. ssp. salzmannii Forest
}

\author{
Manuel Esteban Lucas-Borja ${ }^{1, * \mathbb{C}}$, Arun K. Bose ${ }^{2,3}$, Enrique Andivia ${ }^{4}$, David Candel-Pérez ${ }^{5}$, \\ Pedro A. Plaza-Álvarez ${ }^{1}$ (D) and Juan C. Linares ${ }^{6}$ \\ 1 Departamento de Ciencia y Tecnología Agroforestal y Genética, Escuela Técnica Superior de Ingenieros \\ Agrónomos, Universidad de Castilla-La Mancha, Campus Universitario s/n, 02071 Albacete, Spain; \\ Pedro.Plaza@uclm.es \\ 2 WSL Swiss Federal Institute for Forest, Snow and Landscape Research, Zürcherstrasse 111, \\ CH-8903 Birmensdorf, Switzerland; arun.bose@wsl.ch \\ 3 Forestry and Wood Technology Discipline, Khulna University, Khulna 9201, Bangladesh \\ 4 Departamento de Biodiversidad, Ecología y Evolución, Facultad de Ciencias Biológicas, Universidad \\ Complutense de Madrid, C/José Antonio Novais 12, 28040 Madrid, Spain; eandivia@ucm.es \\ 5 Institute for Multidisciplinary Research in Applied Biology (IMAB), Universidad Pública de Navarra, \\ 31006 Pamplona, Spain; david.candelperez@una.es \\ 6 Departamento de Sistemas Físicos, Químicos y Naturales, Universidad Pablo de Olavide, 41013 Sevilla, Spain; \\ jclincal@upo.es \\ check for \\ * Correspondence: ManuelEsteban.Lucas@uclm.es
} updates

Citation: Lucas-Borja, M.E.; Bose, A.K.; Andivia, E.; Candel-Pérez, D.; Plaza-Álvarez, P.A.; Linares, J.C. Assessing Tree Drought Resistance and Climate-Growth Relationships under Different Tree Age Classes in a Pinus nigra Arn. ssp. salzmannii Forest. Forests 2021, 12, 1161. https:// doi.org/10.3390/f12091161

Academic Editor:

Giovanna Battipaglia

Received: 13 July 2021

Accepted: 24 August 2021

Published: 27 August 2021

Publisher's Note: MDPI stays neutral with regard to jurisdictional claims in published maps and institutional affiliations.

Copyright: (c) 2021 by the authors. Licensee MDPI, Basel, Switzerland. This article is an open access article distributed under the terms and conditions of the Creative Commons Attribution (CC BY) license (https:/ / creativecommons.org/licenses/by/ $4.0 /)$.

\begin{abstract}
The magnitude of drought impact in forest ecosystems depends on which group of trees are more severely affected; greater mortality of smaller trees can modulate the trajectories of succession, while the mortality of larger trees can disproportionately offset the ecosystem's carbon balance. Several studies have documented a greater vulnerability of large trees to extreme droughts while some other studies reported a greater growth reduction in smaller trees during droughts. We tested these hypotheses by comparing tree basal area increment (BAI), drought resistance (i.e., magnitude of growth decline during drought), and resilience (i.e., magnitude of growth recovery after drought) across five different age-classes in black pine (Pinus nigra Arn. ssp. salzmannii) forests in Spain. Our results showed that the BAI patterns, drought resistance, and resilience were strongly influenced by tree age-classes. In addition, the effect of climatic water balance (precipitation minus potential evapotranspiration) on BAI significantly varied among age-classes. The effect of water balance on BAI was lower for younger age-classes (1-39 years of age) compared to older age-classes. We observed a greater growth reduction (i.e., lower resistance) in older trees ( $>40$ years of age) during droughts compared to younger trees $(<40$ years of age). However, all trees, irrespective of their ages, were able to recover the growth rates after the drought. In general, younger trees showed a greater capacity in recovering the growth rate (i.e., more resilient) than older trees. We detected no significant effects of stand basal area and stand density on BAI, drought resistance, and resilience. Overall, our results indicated that growth of older trees was more negatively affected during drought. Therefore, these older/larger trees can be selected for commercial thinning, or can be released from competition, which can minimize the potential impacts of future droughts in black pine forests in Spain.
\end{abstract}

Keywords: climate change; drought; black pine; resistance; resilience

\section{Introduction}

Climate observations at a global scale indicate an increased frequency and severity of drought events [1], though uncertainties remain concerning the responses of tree species to extreme droughts [2]. Tree growth responses to droughts depend on tree and stand characteristics [3-5]. Although several studies have investigated the potential impacts of 
droughts in drought-prone forests (e.g., [6-8]), we still need research focusing on identifying the morphological characteristics of vulnerable individuals across different species to accurately prepare and understand drought responses in forests [9]. Several studies have documented a greater vulnerability of large trees to extreme droughts $[10,11]$ while some other studies reported a greater growth reduction in smaller trees during droughts [12,13]. These divergent response patterns emphasize the importance of identifying trees (size or age classes) within specific ecosystems that are most vulnerable to droughts [14,15].

Climate projections predict a decrease in annual mean precipitation for the Mediterranean Basin [16,17]. Precipitation variability could be particularly important as extreme events, such as extended droughts, could have much more drastic consequences on tree growth and survival than gradual changes in the average climate conditions $[18,19]$. Thus, if the frequency of extreme droughts in Mediterranean areas increases in the future, it could lead to a reduction in forest productivity and changes in species composition $[20,21]$. Tree growth responses of different tree age-classes to long-term temperature trends and extreme drought events are not clearly understood, especially in managed Mediterranean forest ecosystems (but see, for example, [22]). Different researchers have found either enhancement or decline responses in radial growth to increasing temperatures, with no clear trend defined at each age-class [23-26]. An increase in temperature alone would be beneficial for populations located in northern or high-altitude edge of their geographic distribution, but an interaction with other climate- or site-related factors could alter the response [27]. However, a positive effect of temperature increase is not expected in Mediterranean forests as warming effects on evapotranspiration can result in soil water deficits [28,29]. In addition, the low soil water retention capacity in Mediterranean region can limit the positive effect of temperature increase on tree growth. Indeed, mountainous areas of the Mediterranean basin may experience somewhat higher increases in temperature compared to the surrounding regions [17], which could increase the vulnerability of the Mediterranean mountain forests to climate change.

Climate-tree growth relationships of coniferous species have mostly been investigated across unmanaged ecosystems [30-34], and few studies have examined the responses in the mountainous regions of the Mediterranean basin, which are, on one edge, subjected to both water-stress and high elevation-related low temperatures, but also, at lower elevations, overcoming relatively high temperature during the dry summer period $[25,28,35-37]$. Currently decreasing precipitation and increasing temperatures, together with a higher likelihood of extreme drought events are increasing the vulnerability of Mediterranean pine populations [38]. Improving our understanding on the tree drought resistance and climate-growth relationships under different tree age-classes is of paramount importance to properly manage forest ecosystems, and to better achieve the time of ecosystem recovery after the wide range of abiotic and biotic stresses (i.e., climate change, excessive harvesting, pests and diseases, drought, forest fires, and soil compaction) that threaten forest ecosystems worldwide [38]. Previous studies reported that stand age plausibly regulates ecosystem processes such as decomposition and nutrient cycling [39-44]. For example, [45] showed that decomposition and mineralization processes can be reduced in very old forest stands. On the other hand, young forest stands are often associated with a lower capacity to retain carbon in soil.

In this study, we aimed to investigate trees' basal area increment (BAI), drought resistance (i.e., magnitude of growth reduction during drought), and resilience (i.e., magnitude of growth recovery after drought) of five coexisting black pine (Pinus nigra) age-classes under similar climatic conditions. We hypothesized that BAI, resistance, and resilience will vary among tree age-classes as trees from different age-classes are associated with different abilities for coping with changes in precipitation, temperature, and droughts. For this analysis, we used a temperate forest chronosequence from mid-elevation central-eastern region in Spain to evaluate the link between tree growth and climatic variables under different tree age-classes. 


\section{Materials and Methods}

\subsection{Study Area}

The study forest area ("Los Palancares y Agregados") is located in central-eastern Spain $\left(40^{\circ} 01^{\prime} 50^{\prime \prime} \mathrm{N} ; 1^{\circ} 59^{\prime} 10^{\prime \prime} \mathrm{W}\right.$; Figure 1$)$ inside the largest nature reserve in Castilla La Mancha (18,078 ha).

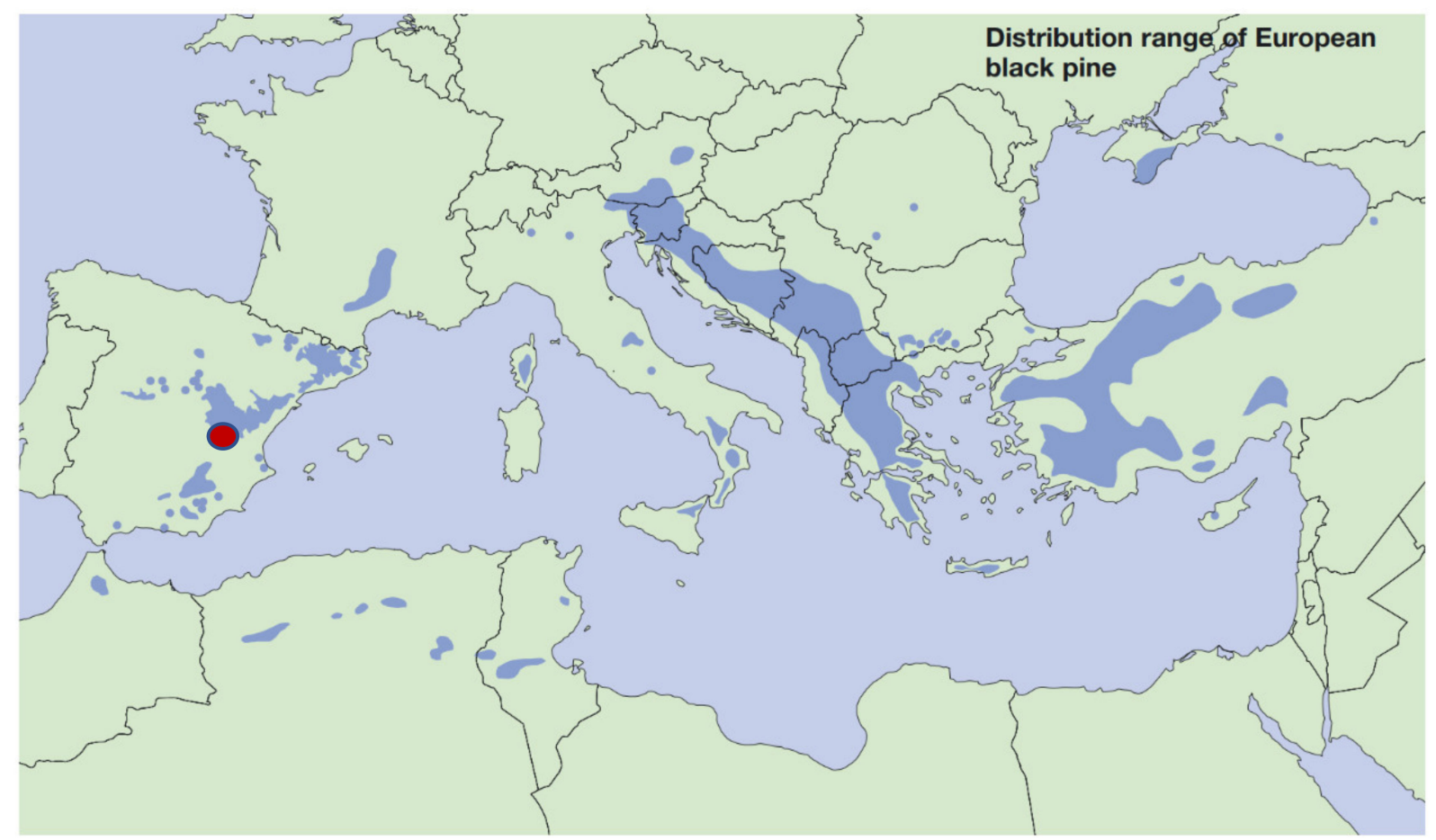

Figure 1. Location of the Pinus nigra Arn. salzmannii sites (red ellipse). The map shows the distribution of Pinus nigra Arn. across the Mediterranean Basin according to Euforgen (http://www.euforgen.org/species/pinus-nigra/, accessed on 26 May 2021).

Los Palancares y Agregados forest comprises about 4900 ha and 85 compartments. The shelterwood method was first applied in 1895 as forests management plan, with a shelter-phase of 20 years and a rotation period of 100 years. The shelterwood method has remained in Palancares y Agregados ever since, which resulted in five different age classes in tree population over the past 120 years. The regeneration method used, in both mixed and pure even-aged Spanish black pine stands, involved a uniform opening of the canopy without soil preparation. The main effort of forest management plans has been increasing forest standing stock and transforming age-heterogeneous stands into even-aged. The average elevation of the study area is $1200 \mathrm{~m}$ above sea level. According to [46], the climatic characteristics of the experimental area can be classified as Mediterranean humid, with a mean annual temperature of $11.9^{\circ} \mathrm{C}$ (the mean lowest temperature of the coldest month is $-0.5^{\circ} \mathrm{C}$ and the mean highest temperature of the hottest month is $30.5^{\circ} \mathrm{C}$ ) and mean annual precipitation of $595 \mathrm{~mm}$ ( $99 \mathrm{~mm}$ in summer). The study area is dominated by mix natural forests of Spanish black pine, Holm oak (Quercus ilex L.), Portuguese oak (Quercus faginea Lam), and Spanish juniper (Juniperus thurifera L.). Due to their vulnerability to climate change and land use intensification, this ecosystem is now included in the list of European Union endangered habitats (Resolution 4/1996 by the Convention on the Conservation of European Wildlife and Natural Habitats) and in the Protected Areas listing of the Government of Castilla La Mancha (2/2001, Official Diary of Castilla La Mancha $\mathrm{N}^{\circ}$ 8). According to the USDA soil taxonomy [47], Entisols with a relatively thick undifferentiated upper horizon are present in the experimental area. Generally, this type of 
soil has a dominance of mineral soil materials and absence of distinct pedogenic horizons. Sandy-loam soil texture was present at the Palancares y Agregados forest.

\subsection{Field Sampling and Dendrochronological Methods}

In October 2013, five forest compartments of about 50 ha were randomly selected at the Palancares y Agregados forest area, supporting forest stands of five ages: T1 (age 60-181 years), T2 (age 65-95 years), T3 (age 65-100-59 years), T4 (age 10-90 years), T5 (age $1-809$ years). The forest under an age-class management is characterised by a sequence of relatively homogenous, even-aged stands once the rotation period (100 years) is completed. As the Palancares y Agregados forest management operations started at the end of the 19th century, it has been possible to select different compartments and age stands, ranging from 1 to 100 years old. The main forest structure characteristics of each tree age level were obtained from the current forest management plan develop by Castilla La Mancha Forest Service in 2005. Two stands by age class were selected for the description and quantification of the stand-structure variability along the tree age classes (Table S1). Within each of the ten stands, two plots (c. $0.13 \mathrm{ha}$, located around $1 \mathrm{~km}$ apart) were sampled in order to characterize stand structure. The selected forests quadrats displayed low spatial heterogeneity in tree composition and density [48], hence the plots were large enough to capture the low spatial/range of variability of the stands. All the trees with a diameter greater than $3 \mathrm{~cm}$ at $1.3 \mathrm{~m}$ from the base (diameter at breast height; dbh) were identified, tagged, and mapped, and their diameters were measured (see Figure S1 at Supplementary Material).

Experimental sites and trees were selected in order to find the maximum tree growth response to drought events and the best signal to noise ratio, respectively [34]. None of the stands selected showed evidence of intense perturbations such as fires or windstorm. Stumps were found in some stands as management by the Public Forest Administration under the shelterwood system is applied over the study area. For the quantification of secondary growth across the selected stands, wood cores were obtained from 20 dominant trees per age compartment to build five tree-ring chronologies (one per each age class). Two-three cores per tree at dbh were extracted with a borer, perpendicular to the terrain slope [49]. Trees with asymmetrical growth and a non-circular bole were avoided. Cores were sanded and visually cross-dated using the marker year's method and their ring-width series were measured to the nearest $0.001 \mathrm{~mm}$ by means of a stereomicroscope coupled with a LINTABTM 5 RINNTECH ${ }^{\circledR}$ device linked to a computer. Cross-dating quality was checked using COFECHA [50]. Basal area increment (BAI) was calculated from tree-ring width as a more accurate evidence of annual radial growth around the circumference of the tree. Age-related long-term BAI trend and BAI autocorrelation were removed by fitting raw BAI data versus cambial tree age (tree age at coring height). Long-term BAI trend was then estimated for the whole dataset by polynomial regression (loess) and weights computed from the Gaussian density function [51]. BAI indexes were obtained as the residual chronology, standardized by individuals mean BAI:

$$
\text { Balindex }_{i j}=\frac{\text { observed } B A I_{j}-\text { predicted } B A I_{j}}{\text { mean } B A I_{i}}
$$

where $B A I$ index $i_{i j}$ stands for the value calculated for the year $j$ in the tree $i$; observed $B A I_{j}$ is the raw BAI value of the year $j$ in the tree $i$; predicted $B A I_{j}$ is the BAI value predicted by polynomial regression (loess) for the year $j$; and mean $B A I_{i}$ is the mean BAI of the tree $i$ computed for the entire tree chronology; BAI indexes were tested for age-independence and autocorrelation (see Figure S1 at Supplementary Material).

\subsection{Growth Stability Components in Response to Drought Events}

We considered drought events as those years in which water balance (i.e., precipitation minus potential evapotranspiration (P-PET) was below the $25 \%$ percentile for the studied period (i.e., P-PET $=-277$ ) and tree growth showed a pronounced drop [52]. To evaluate 
this, we used the relative growth change method [53], identifying as drought events those years in which at least $30 \%$ of the trees showed a BAI decrease of at least $30 \%$ relative to the average BAI in the three preceding years. We identified 1981, 1991, 1999, and 2005 as the most intense drought events during the study period (Figure 2). We also identified 1968 as a drought event, but it was not considered in further analyses due to the low number of observations for trees of younger age classes. We evaluated growth resistance and resilience to each drought event using resilience and resistance indices [54]:

$$
\begin{aligned}
\text { Resistance }(\mathrm{Rt}) & =\frac{\mathrm{Dr}}{\mathrm{PreDr}} \\
\text { Resilience }(\mathrm{Rs}) & =\frac{\text { PostDr }}{\text { PreDr }}
\end{aligned}
$$

where PreDr was the average BAI of three years before the drought event; Dr was the BAI during the year of the drought event; and PostDr was the average BAI of three years after the drought event.

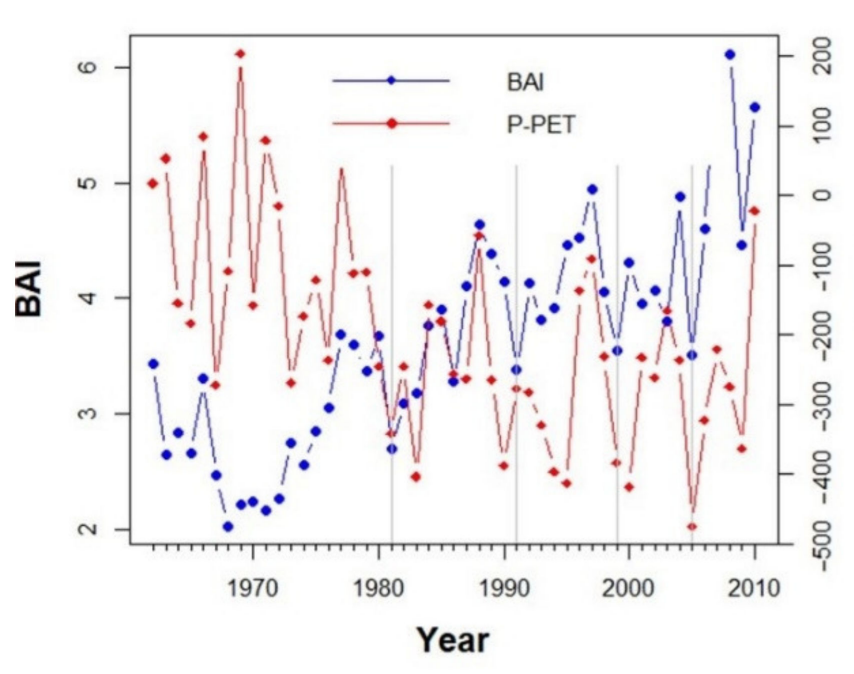

(a)

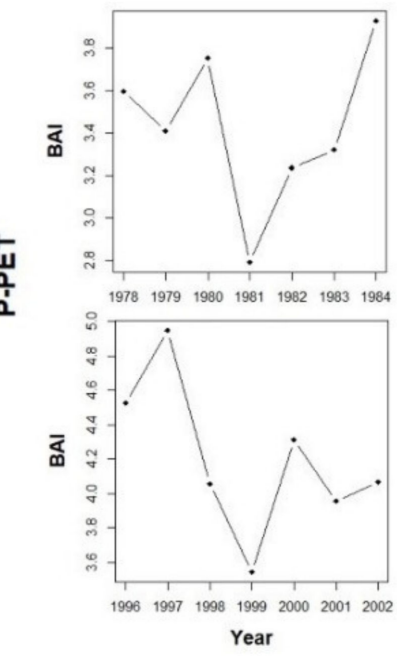

(b)

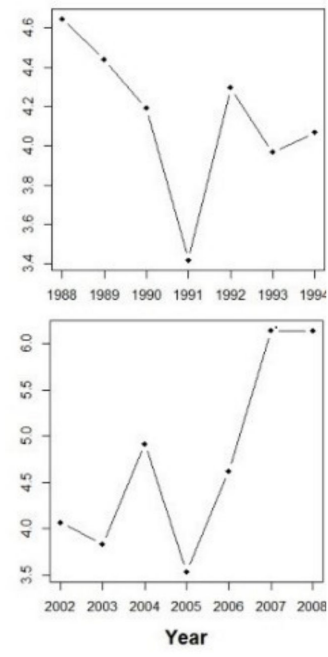

Figure 2. (a) Mean annual Basal Area Increment (BAI, cm) and annual water balance (P-PET, mm) for the studied period (1962-2010). Vertical grey lines depict studied drought events. (b) The right panel shows detailed mean BAI values for each drought event and the three years preceding and following the event.

\subsection{Data Analysis}

We used a linear mixed model to evaluate the main determinants of tree growth (i.e., BAI) and to compare whether trees of different age classes show different responses to water balance. BAI was log-transformed to avoid heteroscedasticity. We considered tree size, age-class, annual water balance, annual temperature, stand density, and stand basal area as fixed effects in the model. Tree size was included as a second order polynomial based on exploratory analyses (Figure S1). We also included as fixed effect the pairwise interaction between age-class and annual water balance. We considered tree identity nested within stand identity as random term to account for non-independency among observations within the same individual (i.e., repeated measurements). We also used an autoregressive correlation structure to remove the first-order autocorrelation between observations. Continuous predictor variables were standardized (i.e., the mean was subtracted from each value and divided by the standard deviation) to allow comparisons across model-estimated parameters [55]. We checked that the explanatory variables did not show high collinearity $(\mathrm{r}<0.6)$. To assess whether growth response to water balance differs between age-classes, we compared the water balance slope for each age-class by using a t-test. We evaluated the percentages of variance explained by fixed and random effects following [56]. We also 
used linear mixed models to evaluate differences between age-classes and the effect of tree size, stand basal area, and density in resilience and resistance indices for each drought event. Resistance and resilience indices were log-transformed to avoid heteroscedasticity. Stand identity was considered as a random term in the model. We used a t-test to evaluate whether differences between species were significantly different from zero. For all models, significant effects were considered at $p<0.05$. All statistical analyses were performed using the programming language $\mathrm{R}$ (version 3.5.3) [57] using the package nlme [58], visreg [59], and pointRes [60].

\section{Results}

\subsection{Characteristics of the Sampled Stands and Trees}

The stand basal area and density ranged from 13.5 to $41.3 \mathrm{~m}^{2} \mathrm{ha}^{-1}$ (mean $\pm \mathrm{SD}$, $27.6 \pm 10.3 \mathrm{~m}^{2} \mathrm{ha}^{-1}$ ) and from 645 to 2769 trees ha ${ }^{-1}\left(1251 \pm 702\right.$ trees ha $\left.{ }^{-1}\right)$, respectively (Table S1). The DBH of the sampled trees ranged from 5.4 to $50.8 \mathrm{~cm}(22.9 \pm 11.5 \mathrm{~cm})$. The main BAI for the studied period was $3.7 \pm 3.3 \mathrm{~cm}^{2}$. Stand basal area was lower for the younger age classes (T4 and T5), whereas stand density decreased with tree age except for T3 (Figure S2). Tree size and mean BAI increased with tree age (Figure S2).

\subsection{Drivers of Tree Basal Area Increment (BAI)}

BAI patterns were strongly influenced by tree size, climatic variables and the interaction between age-class and water balance (Table 1). The percentage of variance explained by both the fixed and random effects was $83 \%$ (conditional pseudo- $\mathrm{R}^{2}$ ) and the fixed effects explained $57 \%$ of variance (marginal pseudo- $\mathrm{R}^{2}$ ). Tree size showed a quadratic effect on BAI (Figure S3) whereas the effect of temperature and water balance was positive (Figure S3, estimated slopes \pm SE, $0.029 \pm 0.05$ and $0.041 \pm 0.07$, respectively). However, the magnitude of the effect of water balance varied across age-classes (i.e., significant interaction).

Table 1. $\mathrm{F}$ and $p$ values for the fixed effects considered in the linear mixed model to analyse basal area increment of black pines for the period 1962-2010. Water balance is the precipitation minus potential evapotranspiration. F-value represents the F-statistics, i.e., ratio of two measures that are expected to be equal under the null hypothesis, while $p$-value is the probability of obtaining results as the observed results of a statistical hypothesis test.

\begin{tabular}{ccc}
\hline Fixed Effect & F-Value & $p$-Value \\
\hline Size & $\mathbf{3 9 8 . 1 4}$ & $<\mathbf{0 . 0 0 0 1}$ \\
Age-class & 5.63 & 0.0939 \\
Water balance & $\mathbf{1 2 2 . 3 5}$ & $<\mathbf{0 . 0 0 0 1}$ \\
Temperature & $\mathbf{2 9 . 7 0}$ & $<\mathbf{0 . 0 0 0 1}$ \\
Stand basal area & 0.02 & 0.8993 \\
Stand density & 0.15 & 0.7251 \\
Age-class $\times$ Water balance & $\mathbf{3 . 8 8}$ & $\mathbf{0 . 0 0 3 8}$ \\
\hline
\end{tabular}

Note: Significant differences in bold.

The effect of water balance on BAI was lower for younger age-classes (T4 and T5) compared to middle age-class (T3), while the older age-classes (T1 and T2) showed intermediate response (Figure 3). Stand basal area and density showed a non-significant positive effect on BAI (estimated slopes $\pm \mathrm{SE}, 0.449 \pm 0.475$, and $0.297 \pm 0.210$, respectively). 


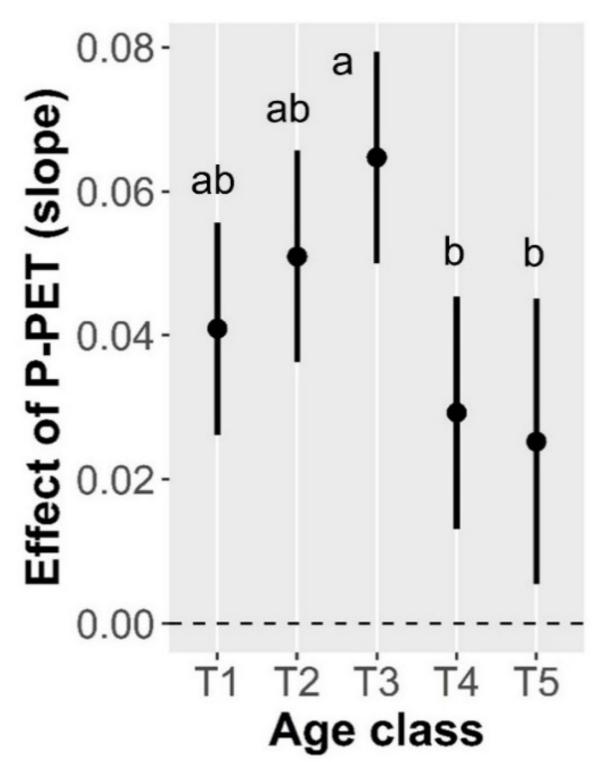

Figure 3. Estimated effect of water balance (P-PET) on black pine basal area increment for each age class. Whiskers represent $95 \%$ confidence intervals of the estimated effect. Different letters show statistically significant differences between age classes $(p<0.05)$.

\subsection{Resilience and Resistance to Drought Events}

We found BAI reduction in response to studied droughts compared to the three years preceding the events (Figure 2). On average, tree BAI was reduced by $13 \%, 26 \%, 25 \%$, and $12 \%$ in response to 1981, 1991, 1999, and 2005 drought events, respectively. However, the magnitude of the growth reduction varied not only between drought events but also between age-classes (Figure S4). In general, older trees (T1, T2, and T3) showed greater growth reductions than younger trees (Figure $\mathrm{S} 4$ ).

Trees of different age-classes showed significant differences in the resilience and resistance to the studied drought events (Table 2, Figures 4 and 5). Tree size showed a consistent negative effect on tree BAI resilience to droughts. However, the effect was statistically significant only for the 2005 drought (Table 2). Stand basal area and stand density did not show statistically significant effects on resistance and resilience. Resilience indices to droughts generally showed values higher than 1.0 (Figure 4) indicating that most of the individuals recovered growth rates three years after the drought event. Differences in the resilience index between age-classes were not consistent between drought events. Trees of the T4 age class showed the greatest and lowest resilience in response to 1981 and 2005 droughts, respectively (Figure 4). Youngest trees (i.e., T5) showed the greater resilience to the two more recent drought events compared to older trees. However, in response to the 2005 drought, oldest trees showed similar resilience to youngest (Figure 4). We did not find statistically significant differences between age-classes in response to the 1991 drought. Resistance indices were generally lower than 1.0 reflecting the impact of the studied drought events on tree growth (Figure 4). Trees of the T3 age class showed consistently the lowest resistance to drought events except for the 2005 drought when the $\mathrm{T} 4$ had the lowest resistance. However, the resistance of the T3 cohort was not statistically different from T1 in 1981, T2 in 1991, T1 and T2 in 1999, and all but T5 in 2005 (Figure 4). The youngest trees showed the greatest resistance to the two recent droughts, but for 2005, the resistance of all age classes but T4 are statistically non-significant (Figure 5). 
Table 2. F and $p$ values for the fixed effects considered in the linear mixed models to analyse resilience and resistance of black pines to studied drought events. Significant effects at $p<0.05$ are shown in bold. F-value represents the F-statistics, i.e., ratio of two measures that are expected to be equal under the null hypothesis while $p$-value is the probability of obtaining results as the observed results of a statistical hypothesis test.

\begin{tabular}{|c|c|c|c|c|c|c|c|c|}
\hline \multirow[b]{2}{*}{ Fixed Effect } & \multicolumn{2}{|c|}{1981} & \multicolumn{2}{|c|}{1991} & \multicolumn{2}{|c|}{1999} & \multicolumn{2}{|c|}{2005} \\
\hline & $F$ & $p$ & $F$ & $p$ & $F$ & $p$ & $F$ & $p$ \\
\hline & \multicolumn{8}{|c|}{ Resilience } \\
\hline Age class & 96.52 & 0.0003 & 2.45 & 0.2419 & 79.41 & 0.0001 & 12.98 & 0.0075 \\
\hline Tree size & 2.33 & 0.1306 & 0.94 & 0.3351 & 2.97 & 0.0885 & 7.37 & 0.0080 \\
\hline Stand basal area & 5.42 & 0.1022 & 0.03 & 0.8784 & 0.03 & 0.8765 & 4.83 & 0.1153 \\
\hline \multirow[t]{2}{*}{ Stand density } & 0.13 & 0.7444 & 1.50 & 0.3046 & 0.38 & 0.5795 & 0.17 & 0.7073 \\
\hline & \multicolumn{8}{|c|}{ Resistance } \\
\hline Age class & 7.56 & 0.0238 & 7.92 & 0.0217 & 28.06 & 0.0013 & 5.73 & 0.0414 \\
\hline Tree size & 0.01 & 0.9373 & 0.31 & 0.5803 & 0.60 & 0.4420 & 0.14 & 0.7130 \\
\hline Stand basal area & 0.12 & 0.7486 & 0.60 & 0.4949 & 0.75 & 0.4488 & 0.49 & 0.5336 \\
\hline Stand density & 0.48 & 0.5398 & 0.08 & 0.7893 & 0.21 & 0.6776 & 0.87 & 0.4198 \\
\hline
\end{tabular}
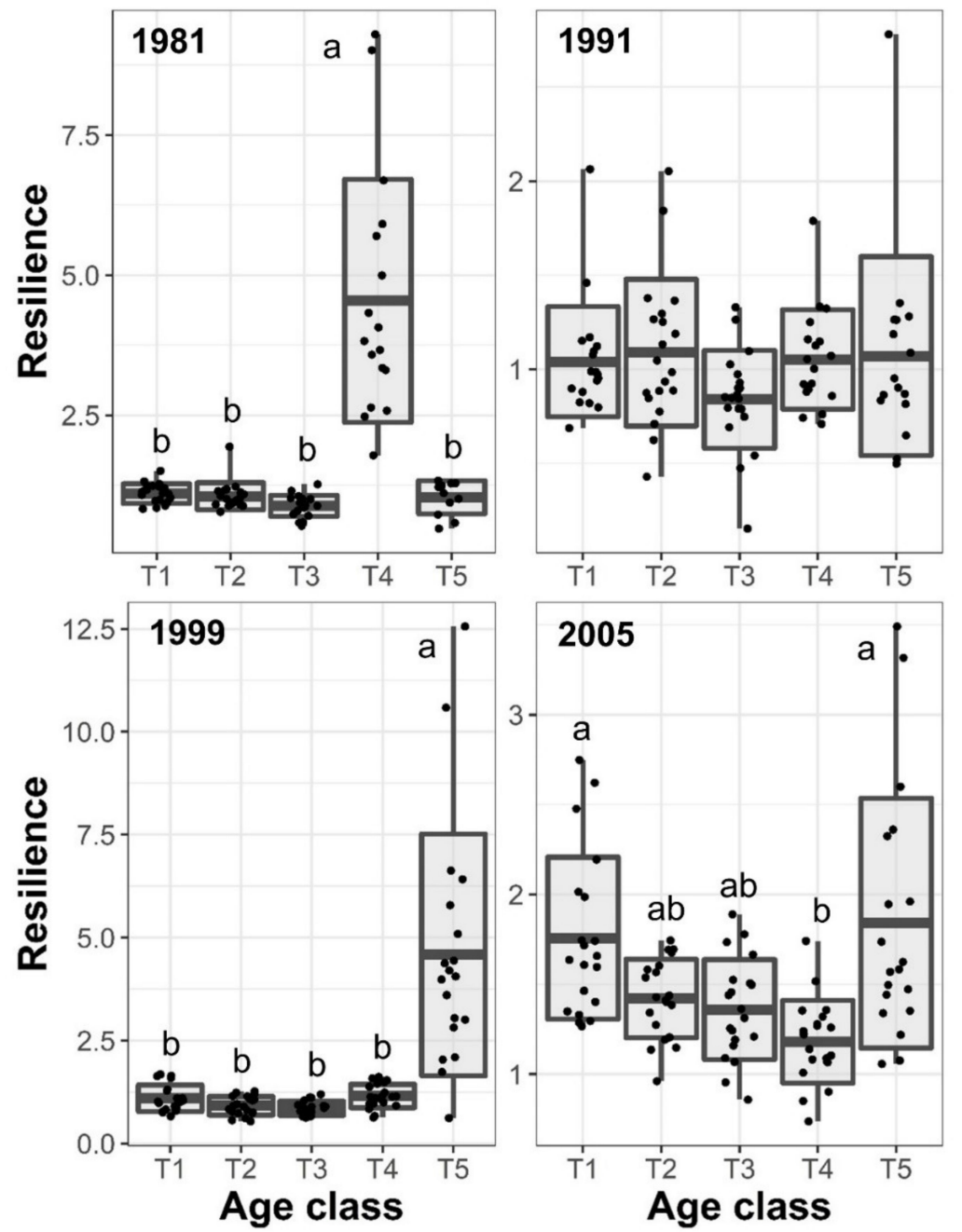

Figure 4. Boxplot of estimated resilience to each studied drought event and black pine age classes. Points depict estimated values. Different letters show statistically significant differences between age classes $(p<0.05)$. 

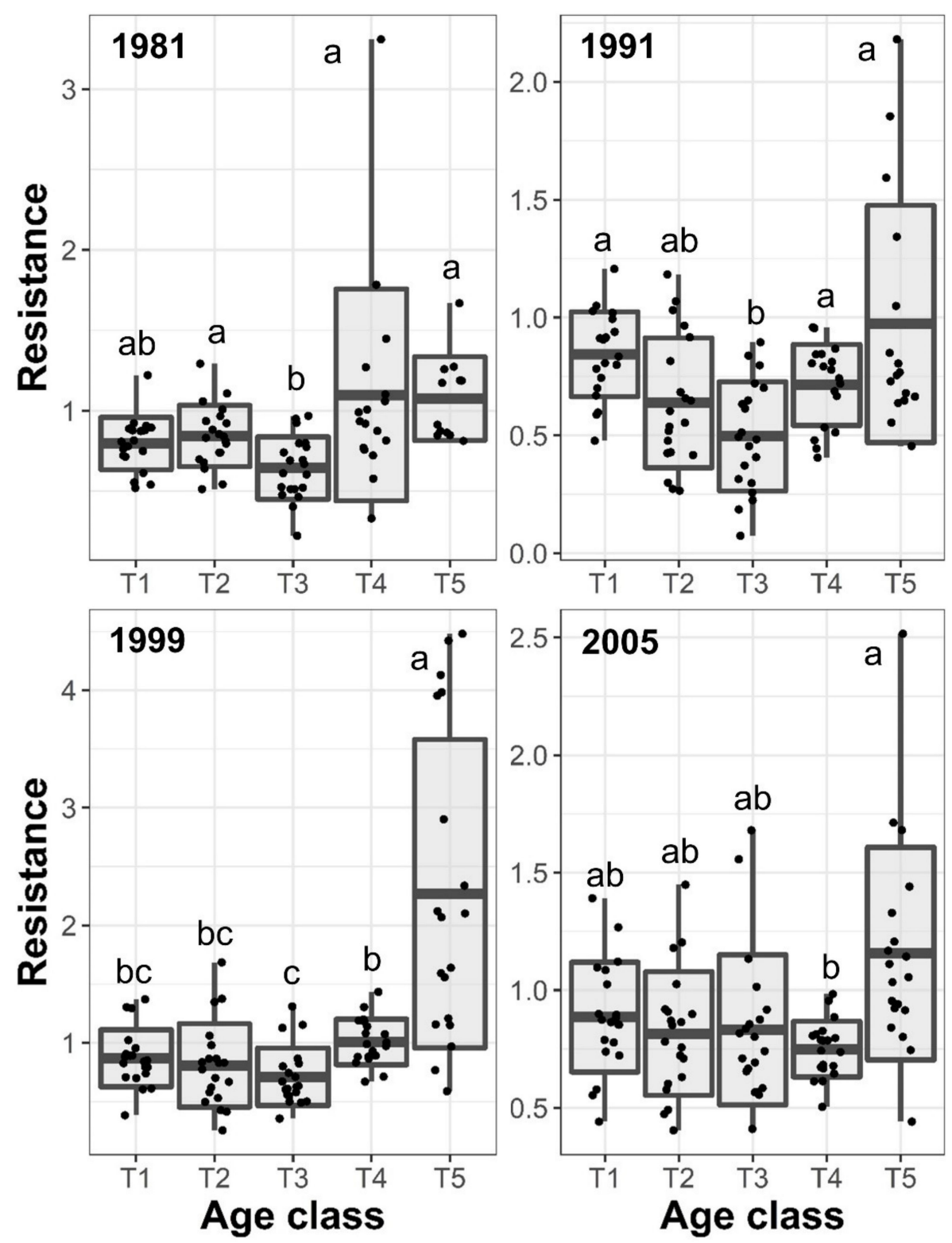

Figure 5. Boxplot of estimated resistance to each studied drought event and black pine age-classes. Points depict estimated values. Different letters show statistically significant differences between age classes $(p<0.05)$.

\section{Discussion}

Pinus nigra has been increasingly reported as vulnerable tree species to extreme droughts $[28,61]$ as the species is sensitive to drought-induced xylem dysfunction and associated tree dieback $[62,63]$. With the increasing frequency and severity of extreme droughts in the Mediterranean region [64] the understanding of Pinus nigra' growth and physiological performances during and after droughts are gaining research priorities (e.g., [65-67]). In the present study, we aimed to understand how the trees from five different age-classes of Pinus nigra responded to extreme drought events and what are the tree-, site-, and climate-related factors that have modified those response patterns.

Our study identified significant differences among tree age-classes of managed Pinus nigra forest stands in terms of basal area increment (BAI), drought resistance, and drought resilience. These results support the argument that tree age can modify the drought impact in forest stands $[14,68,69]$. Our results showed that younger trees ( $<40$ years of age) were more resistant and resilient to extreme droughts which occurred in 1981, 1991, 1999, and 
2005 compared to older trees (40-120 years of age) (Figures 4 and 5). The older trees, which were larger in size (Figure S2), might have faced a greater hydraulic challenge compared to smaller trees, as they had to lift the water to a longer distance from roots to crown against the effects of gravity [70,71]. In addition, larger trees are often associated with crowns directly exposed to increased solar radiation and evaporative demand during drought events $[10,72]$. Thus, microclimate conditions at the scale of individual trees may play an important role together with tree size. The exposure to an increased evaporative demand can adversely affect the larger trees when they try to maintain the stomata open for $\mathrm{C}$ assimilation [73]. A similar finding, i.e., higher growth of smaller trees during droughts has been reported by other studies in Europe [11] and in North America [14]. Moreover, larger trees often carry higher photosynthetic tissues compared to smaller trees and holds a higher water requirement for maintaining the photosynthetic activity and for general maintenance of other biological processes [74]. The higher water requirement can make larger trees vulnerable to extreme drought events [71]. Our results have also shown that the BAI of larger or older trees was more strongly correlated with water balance compared to BAI of younger trees (Table 1 ).

Although growth reduction (i.e., lower resistance) was observed during all studied drought years (Figure 5), trees were able to fully recover the growth rates after the droughts, irrespective of tree age-classes (Figure 4). In fact, the growth rate after the droughts was higher than the growth rate prior to droughts, which indicated compensatory growth responses in these trees. The compensatory growth is probably a typical physiological reaction or acclimation strategy in trees to compensate for losses during the drought period $[75,76]$ and could result due to favorable growing conditions after the drought events. However, if the extreme droughts persist several years, the annual growth rate of black pine might drastically decrease. The compensatory growth in trees has been identified by several local [77], continental [78], and global scale studies [79,80] conducted on coniferous as well as on broadleaved species. In the present study, we detected a higher growth compensation in younger trees ( $<20$ years of age) compared to older trees (21-120 years of age) (Figure 4$)$. This also suggests that a younger $(<40$ years of age) Pinus nigra forest is not only resistant but also resilient to extreme drought events in this Mediterranean region.

Stand density and stand basal area are useful indicators of tree-to-tree competition [15]. Previous studies identified a strong influence of stand density on BAI and on drought resistance and resilience of Pinus nigra trees [66]. They demonstrated that the tree-totree competition negatively influenced the BAI and intrinsic water-use efficiency in Pinus nigra trees. In contrast to their findings, we detected no significant effect of stand density or stand basal area on BAI or on drought resistance and resilience. It is important to mention that our study did not measure stand density or stand basal area during those identified drought years, hence provides limited quantitative measures of tree-to-tree competition. In addition, we have limited variability in stand density across studied stands which might have interfered the outcomes of our analyses, i.e., insignificant effect of stand density of resistance and resilience. Our younger Pinus nigra stands are relatively dense in composition (Table S1). This relatively higher stand density could make these forest stands sensitive to future droughts and warming events [66]. Commercial thinning operations could reduce the competition between trees and could increase resilience to upcoming drought events $[5,66,78,81,82]$.

In conclusion, our study showed that all Pinus nigra trees, irrespective of their ages and stand densities, were able to fully recover their annual basal area growth after four individual drought events between 1980 and 2005. Among the studied age-classes, younger age-classes (i.e., younger than 40 years of age) were more resilient compared to older ageclasses (i.e., 41-120 years of age). Forest practitioners can exercise different thinning interventions, especially removing older trees to reduce competition among retained individuals and increase resistance to upcoming drought events. The tree age-dependent 
responses to droughts may indicate that analyses of stand-level responses to drought need to consider tree age-classes.

Drought induced decline in tree growth and forest dieback have been reported in many Pinus nigra forests [62], as well as in other coniferous forest ecosystems in the Mediterranean region $[83,84]$. The lack of forest management can increase tree-to-tree competition by increasing stand density, and this increasing stand density can potentially aggravate the anticipated effects of the increasing frequency and severity of extreme droughts in coming years [85]. Our study showed that younger Pinus nigra stands are more resilient, as well as resistant, to drought events; therefore, promoting a greater presence of young Pinus nigra stands in the forested landscape through forest management [66,82] can enhance the resilience of Mediterranean conifer forests to extreme droughts. However, it is also important to maintain tree size-heterogeneity in thinned stands to avoid structural homogeneity associated vulnerability to extreme drought events.

Supplementary Materials: The following are available online at https:/ / www.mdpi.com/article / 10.3390/f12091161/s1, Table S1: Age class, basal area $\left(\mathrm{m}^{2} \mathrm{ha}^{-1}\right)$, density (No. trees ha $\left.{ }^{-1}\right)$, and mean $( \pm \mathrm{SD}) \mathrm{DBH}(\mathrm{cm})$ of each sampled black pine stand, Figure S1: Relationship between logtransformed Basal Area Increment (BAI) and tree size of sampled black pines $(n=100)$. Grey points represent observations. Black line depicts fitted polynomial regression (loess) to the data, Figure S2: Boxplot of the diameter at breast height $(\mathrm{DBH})$, basal area increment (BAI), stand basal area and density of sampled black pines and stands, Figure S3: Predicted effect (blue lines) of tree size, temperature, and water balance (P-PET) on log-transformed Basal Area Increment (BAI) of sampled black pines $(n=100)$. Grey belts and grey points show $95 \%$ confident intervals for model predictions and observations, respectively, Figure S4: Mean Basal Area Increment (BAI) for age class and for each drought event and the three years preceding and following the event. Drought events identified in 1981, 1991, 1999, and 2005 (black vertical line).

Author Contributions: M.E.L.-B., D.C.-P., and P.A.P.-Á.; fieldwork. M.E.L.-B., D.C.-P., P.A.P.-Á., and J.C.L.; Conceptualization and methodology. E.A.; Data analysis. M.E.L.-B., D.C.-P., P.A.P.-Á., E.A., A.K.B. and J.C.L.: writing, review, and editing. All authors have read and agreed to the published version of the manuscript.

Funding: This research received no external funding.

Data Availability Statement: Data availability upon request.

Acknowledgments: Pedro Antonio Plaza Álvarez was supported by a predoctoral fellowship from the Spanish Ministry of Education, Culture and Sport (FPU16/03296).

Conflicts of Interest: The authors declare no conflict of interest.

\section{References}

1. Dai, A. Increasing Drought under Global Warming in Observations and Models. Nat. Clim. Chang. 2013, 3, 52-58. [CrossRef]

2. Allen, C.D.; Macalady, A.K.; Chenchouni, H.; Bachelet, D.; McDowell, N.; Vennetier, M.; Kitzberger, T.; Rigling, A.; Breshears, D.D.; Hogg, E.H.T. A Global Overview of Drought and Heat-Induced Tree Mortality Reveals Emerging Climate Change Risks for Forests. For. Ecol. Manag. 2010, 259, 660-684. [CrossRef]

3. Andrews, C.M.; D’Amato, A.W.; Fraver, S.; Palik, B.; Battaglia, M.A.; Bradford, J.B. Low Stand Density Moderates Growth Declines during Hot Droughts in Semi-arid Forests. J. Appl. Ecol. 2020, 57, 1089-1102. [CrossRef]

4. Bose, A.K.; Nelson, A.S.; Kane, M.; Rigling, A. Density Reduction in Loblolly Pine (Pinus Taeda L.) Stands to Increase Tree C Assimilation: An Approach with the Dual $\delta 13 \mathrm{C}$ and $\delta 18$ O Isotope Signatures in Needles. Ann. For. Sci. 2018, 75, 1-12. [CrossRef]

5. Bottero, A.; Forrester, D.I.; Cailleret, M.; Kohnle, U.; Gessler, A.; Michel, D.; Bose, A.K.; Bauhus, J.; Bugmann, H.; Cuntz, M. Growth Resistance and Resilience of Mixed Silver Fir and Norway Spruce Forests in Central Europe: Contrasting Responses to Mild and Severe Droughts. Glob. Chang. Biol. 2021. [CrossRef] [PubMed]

6. Bose, A.K.; Gessler, A.; Bolte, A.; Bottero, A.; Buras, A.; Cailleret, M.; Camarero, J.J.; Haeni, M.; Hereş, A.; Hevia, A. Growth and Resilience Responses of Scots Pine to Extreme Droughts across Europe Depend on Predrought Growth Conditions. Glob. Chang. Biol. 2020, 26, 4521-4537. [CrossRef]

7. Sánchez-Salguero, R.; Camarero, J.J.; Hevia, A.; Madrigal-González, J.; Linares, J.C.; Ballesteros-Canovas, J.A.; Sánchez-Miranda, A.; Alfaro-Sánchez, R.; Sangüesa-Barreda, G.; Galván, J.D. What Drives Growth of Scots Pine in Continental Mediterranean Climates: Drought, Low Temperatures or Both? Agric. For. Meteorol. 2015, 206, 151-162. [CrossRef] 
8. Zang, C.; Hartl-Meier, C.; Dittmar, C.; Rothe, A.; Menzel, A. Patterns of Drought Tolerance in Major European Temperate Forest Trees: Climatic Drivers and Levels of Variability. Glob. Chang. Biol. 2014, 20, 3767-3779. [CrossRef]

9. Lévesque, M.; Saurer, M.; Siegwolf, R.; Eilmann, B.; Brang, P.; Bugmann, H.; Rigling, A. Drought Response of Five Conifer Species under Contrasting Water Availability Suggests High Vulnerability of Norway Spruce and European Larch. Glob. Chang. Biol. 2013, 19, 3184-3199. [CrossRef]

10. Bennett, A.C.; McDowell, N.G.; Allen, C.D.; Anderson-Teixeira, K.J. Larger Trees Suffer Most during Drought in Forests Worldwide. Nat. Plants 2015, 1, 1-5. [CrossRef]

11. Pretzsch, H.; Schütze, G.; Biber, P. Drought Can Favour the Growth of Small in Relation to Tall Trees in Mature Stands of Norway Spruce and European Beech. For. Ecosyst. 2018, 5, 1-19. [CrossRef]

12. Colangelo, M.; Camarero, J.J.; Borghetti, M.; Gazol, A.; Gentilesca, T.; Ripullone, F. Size Matters a Lot: Drought-Affected Italian Oaks Are Smaller and Show Lower Growth Prior to Tree Death. Front. Plant Sci. 2017, 8, 135. [CrossRef] [PubMed]

13. Van Mantgem, P.J.; Stephenson, N.L.; Byrne, J.C.; Daniels, L.D.; Franklin, J.F.; Fulé, P.Z.; Harmon, M.E.; Larson, A.J.; Smith, J.M.; Taylor, A.H. Widespread Increase of Tree Mortality Rates in the Western United States. Science 2009, 323, 521-524. [CrossRef] [PubMed]

14. D'Amato, A.W.; Bradford, J.B.; Fraver, S.; Palik, B.J. Effects of Thinning on Drought Vulnerability and Climate Response in North Temperate Forest Ecosystems. Ecol. Appl. 2013, 23, 1735-1742. [CrossRef]

15. Forrester, D.I. Linking Forest Growth with Stand Structure: Tree Size Inequality, Tree Growth or Resource Partitioning and the Asymmetry of Competition. For. Ecol. Manag. 2019, 447, 139-157. [CrossRef]

16. Sumner, G.N.; Romero, R.; Homar, V.; Ramis, C.; Alonso, S.; Zorita, E. An Estimate of the Effects of Climate Change on the Rainfall of Mediterranean Spain by the Late Twenty First Century. Clim. Dyn. 2003, 20, 789-805. [CrossRef]

17. Solomon, S.; Manning, M.; Marquis, M.; Qin, D. Climate Change 2007-the Physical Science Basis: Working Group I Contribution to the Fourth Assessment Report of the IPCC; Cambridge University Press: Cambridge, UK, 2007; Volume 4, ISBN 0521705967.

18. Loustau, D.; Bosc, A.; Colin, A.; Ogée, J.; Davi, H.; François, C.; Dufrêne, E.; Déqué, M.; Cloppet, E.; Arrouays, D. Modeling Climate Change Effects on the Potential Production of French Plains Forests at the Sub-Regional Level. Tree Physiol. 2005, 25, 813-823. [CrossRef] [PubMed]

19. Granier, A.; Reichstein, M.; Breda, N.; Janssens, I.A.; Falge, E.; Ciais, P.; Grünwald, T.; Aubinet, M.; Berbigier, P.; Bernhofer, C. Evidence for Soil Water Control on Carbon and Water Dynamics in European Forests during the Extremely Dry Year: 2003. Agric. For. Meteorol. 2007, 143, 123-145. [CrossRef]

20. Martínez-Vilalta, J.; López, B.C.; Adell, N.; Badiella, L.; Ninyerola, M. Twentieth Century Increase of Scots Pine Radial Growth in NE Spain Shows Strong Climate Interactions. Glob. Chang. Biol. 2008, 14, 2868-2881. [CrossRef]

21. Allen, C.D. Climate-Induced Forest Dieback: An Escalating Global Phenomenon. Unasylva 2009, 231, 60.

22. Adams, J. Vegetation-Climate Interaction: How Plants Make the Global Environment; Springer Science \& Business Media: Berlin/Heidelberg, Germany, 2009; ISBN 364200881X.

23. Boisvenue, C.; Running, S.W. Impacts of Climate Change on Natural Forest Productivity-Evidence since the Middle of the 20th Century. Glob. Chang. Biol. 2006, 12, 862-882. [CrossRef]

24. Andreu, L.; Gutierrez, E.; Macias, M.; Ribas, M.; Bosch, O.; Camarero, J.J. Climate Increases Regional Tree-growth Variability in Iberian Pine Forests. Glob. Chang. Biol. 2007, 13, 804-815. [CrossRef]

25. Linares, J.C.; Tíscar, P.A. Buffered Climate Change Effects in a Mediterranean Pine Species: Range Limit Implications from a Tree-Ring Study. Oecologia 2011, 167, 847-859. [CrossRef] [PubMed]

26. Vaganov, E.A.; Hughes, M.K.; Shashkin, A. V Growth Dynamics of Conifer Tree Rings: Images of Past and Future Environments; Springer Science \& Business Media: Berlin/Heidelberg, Germany, 2006; Volume 183, ISBN 3540312986.

27. Keeling, C.D.; Chin, J.F.S.; Whorf, T.P. Increased Activity of Northern Vegetation Inferred from Atmospheric $\mathrm{CO}_{2}$ Measurements. Nature 1996, 382, 146-149. [CrossRef]

28. Linares, J.C.; Tíscar, P.A. Climate Change Impacts and Vulnerability of the Southern Populations of Pinus Nigra Subsp. Salzmannii. Tree Physiol. 2010, 30, 795-806. [CrossRef] [PubMed]

29. Sabaté, S.; Gracia, C.A.; Sánchez, A. Likely Effects of Climate Change on Growth of Quercus Ilex, Pinus Halepensis, Pinus Pinaster, Pinus Sylvestris and Fagus Sylvatica Forests in the Mediterranean Region. For. Ecol. Manag. 2002, 162, 23-37. [CrossRef]

30. Antonova, G.F.; Cherkashin, V.P.; Stasova, V.V.; Varaksina, T.N. Daily Dynamics in Xylem Cell Radial Growth of Scots Pine (Pinus Sylvestris L.). Trees 1995, 10, 24-30. [CrossRef]

31. Rossi, S.; Deslauriers, A.; Anfodillo, T.; Morin, H.; Saracino, A.; Motta, R.; Borghetti, M. Conifers in Cold Environments Synchronize Maximum Growth Rate of Tree-ring Formation with Day Length. New Phytol. 2006, 170, 301-310. [CrossRef]

32. Ko Heinrichs, D.; Tardif, J.C.; Bergeron, Y. Xylem Production in Six Tree Species Growing on an Island in the Boreal Forest Region of Western Quebec, Canada. Botany 2007, 85, 518-525. [CrossRef]

33. Camarero, J.J. Direct and indirect effects of the North Atlantic Oscillation on tree growth and forest decline in northeastern Spain. In Hydrological, Socioeconomic and Ecological Impacts of the North Atlantic Oscillation in the Mediterranean Region; Springer: Berlin/Heidelberg, Germany, 2011; pp. 129-152.

34. Carrer, M. Individualistic and Time-Varying Tree-Ring Growth to Climate Sensitivity. PLoS ONE 2011, 6, e22813. [CrossRef]

35. De Luis, M.; Gričar, J.; Čufar, K.; Raventós, J. Seasonal Dynamics of Wood Formation in Pinus Halepensis from Dry and Semi-Arid Ecosystems in Spain. IAWA J. 2007, 28, 389-404. [CrossRef] 
36. Martín-Benito, D.; Del Río, M.; Cañellas, I. Black Pine (Pinus Nigra Arn.) Growth Divergence along a Latitudinal Gradient in Western Mediterranean Mountains. Ann. For. Sci. 2010, 67, 401. [CrossRef]

37. Martin-Benito, D.; Kint, V.; Del Rio, M.; Muys, B.; Cañellas, I. Growth Responses of West-Mediterranean Pinus Nigra to Climate Change Are Modulated by Competition and Productivity: Past Trends and Future Perspectives. For. Ecol. Manag. 2011, 262, 1030-1040. [CrossRef]

38. Ferguson, I.S. Sustainable Forest Management; Oxford University Press: Australia, 1996; ISBN 0195506286.

39. Entry, J.A.; Emmingham, W.H. Influence of Forest Age on Forms of Carbon in Douglas-Fir Soils in the Oregon Coast Range. Can. J. For. Res. 1998, 28, 390-395. [CrossRef]

40. Mund, M.; Schulze, E. Impacts of Forest Management on the Carbon Budget of European Beech (Fagus Sylvatica) Forests. Allg. Forst Jagdztg. 2006, 177, 47.

41. Jandl, R.; Lindner, M.; Vesterdal, L.; Bauwens, B.; Baritz, R.; Hagedorn, F.; Johnson, D.W.; Minkkinen, K.; Byrne, K.A. How Strongly Can Forest Management Influence Soil Carbon Sequestration? Geoderma 2007, 137, 253-268. [CrossRef]

42. Hedo, J.; Lucas-Borja, M.E.; Wic, C.; Andrés-Abellán, M.; de Las Heras, J. Soil Microbiological Properties and Enzymatic Activities of Long-Term Post-Fire Recovery in Dry and Semiarid Aleppo Pine (Pinus Halepensis M.) Forest Stands. Solid Earth 2015, 6, 243-252. [CrossRef]

43. Lucas-Borja, M.E.; Hedo, J.; Cerdá, A.; Candel-Pérez, D.; Viñegla, B. Unravelling the Importance of Forest Age Stand and Forest Structure Driving Microbiological Soil Properties, Enzymatic Activities and Soil Nutrients Content in Mediterranean Spanish Black Pine (Pinus Nigra Ar. Ssp. Salzmannii). Sci. Total Environ. 2016, 562, 145-154. [CrossRef]

44. Lucas-Borja, M.E.; Ahrazem, O.; Candel-Pérez, D.; Moya, D.; Fonseca, T.; Tecles, E.H.; De las Heras, J.; Gómez-Gómez, L. Evaluation of Fire Recurrence Effect on Genetic Diversity in Maritime Pine (Pinus Pinaster Ait.) Stands Using Inter-Simple Sequence Repeat Profiles. Sci. Total Environ. 2016, 572, 1322-1328. [CrossRef]

45. Bauhus, J.; Pare, D. Effects of Tree Species, Stand Age and Soil Type on Soil Microbial Biomass and Its Activity in a Southern Boreal Forest. Soil Biol. Biochem. 1998, 30, 1077-1089. [CrossRef]

46. Allue Andrade, J.L. Phytoclimatic Atlas of Spain. In Phytoclimatic atlas of Spain. Taxonomies; Ministerio de Agricultura Pesca y Alimentación: Madrid, Spain, 1990.

47. Staff, S.S. Keys to Soil Taxonomy; Department of Agriculture: Washington, DC, USA, 2014.

48. Candel-Pérez, D.; Lucas-Borja, M.E.; Linares, J.C. Predicciones Del Crecimiento En Poblaciones de Pino Laricio (Pinus Nigra Arn. Ssp. Salzmannii) Bajo Diferentes Escenarios Futuros de Cambio Climático. Rev. Ecosistemas 2012, 21, 41-49. [CrossRef]

49. Fritts, H.C. The Climate-Growth System. In Tree-Ring Climate; Academic Press: London, UK, 1976; pp. 207-242. ISBN 9780122684500. Available online: https:/ / doi.org/10.1016/B978-0-12-268450-0.X5001-0 (accessed on 7 August 2021). [CrossRef]

50. Holmes, R.L. Program COFECHA User's Manual; Laboratory of Tree-Ring Research, The University of Arizona: Tucson, Arizona, 1983.

51. Zuur, A.; Ieno, E.N.; Smith, G.M. Analyzing Ecological Data; Springer: Berlin/Heidelberg, Germany, $2007 ;$ ISBN 0387459723.

52. Vicente-Serrano, S.M.; Lasanta, T.; Gracia, C. Aridification Determines Changes in Forest Growth in Pinus Halepensis Forests under Semiarid Mediterranean Climate Conditions. Agric. For. Meteorol. 2010, 150, 614-628. [CrossRef]

53. Schweingruber, F.H.; Eckstein, D.; Serre-Bachet, F.; Bräker, O.U. Identification, Presentation and Interpretation of Event Years and Pointer Years in Dendrochronology. Dendrochronologia 1990, 8, 9-38.

54. Lloret, F.; Keeling, E.G.; Sala, A. Components of Tree Resilience: Effects of Successive Low-growth Episodes in Old Ponderosa Pine Forests. Oikos 2011, 120, 1909-1920. [CrossRef]

55. Zuur, A.; Ieno, E.N.; Walker, N.; Saveliev, A.A.; Smith, G.M. Mixed Effects Models and Extensions in Ecology with R; Springer Science \& Business Media: Berlin/Heidelberg, Germany, 2009; ISBN 0387874585.

56. Nakagawa, S.; Schielzeth, H. A General and Simple Method for Obtaining R2 from Generalized Linear Mixed-effects Models. Methods Ecol. Evol. 2013, 4, 133-142. [CrossRef]

57. Team, R.C. R: A Language and Environment for Statistical Computing; R Foundation for Statistical Computing: Vienna, Austria, 2018.

58. Pinheiro, J.; Bornkamp, B.; Glimm, E.; Bretz, F. Model-based Dose Finding under Model Uncertainty Using General Parametric Models. Stat. Med. 2014, 33, 1646-1661. [CrossRef] [PubMed]

59. Breheny, P.; Burchett, W. Visualization of Regression Models Using Visreg. R J. 2017, 9, 56. [CrossRef]

60. Van der Maaten-Theunissen, M.; van der Maaten, E.; Bouriaud, O. PointRes: An R Package to Analyze Pointer Years and Components of Resilience. Dendrochronologia 2015, 35, 34-38. [CrossRef]

61. Sánchez-Salguero, R.; Camarero, J.J.; Dobbertin, M.; Fernández-Cancio, Á.; Vilà-Cabrera, A.; Manzanedo, R.D.; Zavala, M.A.; Navarro-Cerrillo, R.M. Contrasting Vulnerability and Resilience to Drought-Induced Decline of Densely Planted vs. Natural Rear-Edge Pinus Nigra Forests. For. Ecol. Manag. 2013, 310, 956-967. [CrossRef]

62. González de Andrés, E.; Camarero, J.J. Disentangling Mechanisms of Drought-Induced Dieback in Pinus Nigra Arn. from Growth and Wood Isotope Patterns. Forests 2020, 11, 1339. [CrossRef]

63. Savi, T.; Casolo, V.; Dal Borgo, A.; Rosner, S.; Torboli, V.; Stenni, B.; Bertoncin, P.; Martellos, S.; Pallavicini, A.; Nardini, A. Drought-Induced Dieback of Pinus Nigra: A Tale of Hydraulic Failure and Carbon Starvation. Conserv. Physiol. 2019,7 , coz012. [PubMed]

64. Spinoni, J.; Vogt, J.V.; Naumann, G.; Barbosa, P.; Dosio, A. Will Drought Events Become More Frequent and Severe in Europe? Int. J. Climatol. 2018, 38, 1718-1736. [CrossRef] 
65. Martín-Benito, D.; Del Río, M.; Heinrich, I.; Helle, G.; Cañellas, I. Response of Climate-Growth Relationships and Water Use Efficiency to Thinning in a Pinus Nigra Afforestation. For. Ecol. Manag. 2010, 259, 967-975. [CrossRef]

66. Navarro-Cerrillo, R.M.; Sánchez-Salguero, R.; Rodriguez, C.; Lazo, J.D.; Moreno-Rojas, J.M.; Palacios-Rodriguez, G.; Camarero, J.J. Is Thinning an Alternative When Trees Could Die in Response to Drought? The Case of Planted Pinus Nigra and P. Sylvestris Stands in Southern Spain. For. Ecol. Manag. 2019, 433, 313-324. [CrossRef]

67. Petrucco, L.; Nardini, A.; Von Arx, G.; Saurer, M.; Cherubini, P. Isotope Signals and Anatomical Features in Tree Rings Suggest a Role for Hydraulic Strategies in Diffuse Drought-Induced Die-Back of Pinus Nigra. Tree Physiol. 2017, 37, 523-535. [PubMed]

68. Magnani, F.; Mencuccini, M.; Grace, J. Age-related Decline in Stand Productivity: The Role of Structural Acclimation under Hydraulic Constraints. Plant Cell Environ. 2000, 23, 251-263. [CrossRef]

69. Rukh, S.; Poschenrieder, W.; Heym, M.; Pretzsch, H. Drought Resistance of Norway Spruce (Picea Abies [L.] Karst) and European Beech (Fagus Sylvatica [L.]) in Mixed vs. Monospecific Stands and on Dry vs. Wet Sites. From Evidence at the Tree Level to Relevance at the Stand Level. Forests 2020, 11, 639. [CrossRef]

70. Mencuccini, M. The Ecological Significance of Long-distance Water Transport: Short-term Regulation, Long-term Acclimation and the Hydraulic Costs of Stature across Plant Life Forms. Plant Cell Environ. 2003, 26, 163-182. [CrossRef]

71. Olson, M.E.; Soriano, D.; Rosell, J.A.; Anfodillo, T.; Donoghue, M.J.; Edwards, E.J.; León-Gómez, C.; Dawson, T.; Martínez, J.J.C.; Castorena, M. Plant Height and Hydraulic Vulnerability to Drought and Cold. Proc. Natl. Acad. Sci. USA 2018, 115, 7551-7556. [CrossRef]

72. McDowell, N.; Pockman, W.T.; Allen, C.D.; Breshears, D.D.; Cobb, N.; Kolb, T.; Plaut, J.; Sperry, J.; West, A.; Williams, D.G. Mechanisms of Plant Survival and Mortality during Drought: Why Do Some Plants Survive While Others Succumb to Drought? New Phytol. 2008, 178, 719-739. [CrossRef]

73. Choat, B.; Brodribb, T.J.; Brodersen, C.R.; Duursma, R.A.; López, R.; Medlyn, B.E. Triggers of Tree Mortality under Drought. Nature 2018, 558, 531-539. [CrossRef]

74. Ryan, M.G.; Yoder, B.J. Hydraulic Limits to Tree Height and Tree Growth. Bioscience 1997, 47, 235-242. [CrossRef]

75. Arend, M.; Sever, K.; Pflug, E.; Gessler, A.; Schaub, M. Seasonal Photosynthetic Response of European Beech to Severe Summer Drought: Limitation, Recovery and Post-Drought Stimulation. Agric. For. Meteorol. 2016, 220, 83-89. [CrossRef]

76. Trugman, A.T.; Detto, M.; Bartlett, M.K.; Medvigy, D.; Anderegg, W.R.L.; Schwalm, C.; Schaffer, B.; Pacala, S.W. Tree Carbon Allocation Explains Forest Drought-kill and Recovery Patterns. Ecol. Lett. 2018, 21, 1552-1560. [CrossRef] [PubMed]

77. Ovenden, T.S.; Perks, M.P.; Clarke, T.; Mencuccini, M.; Jump, A.S. Life after Recovery: Increased Resolution of Forest Resilience Assessment Sheds New Light on Post-drought Compensatory Growth and Recovery Dynamics. J. Ecol. 2021. [CrossRef]

78. Bose, A.K.; Scherrer, D.; Camarero, J.J.; Ziche, D.; Babst, F.; Bigler, C.; Bolte, A.; Dorado-Liñán, I.; Etzold, S.; Fonti, P. Climate Sensitivity and Drought Seasonality Determine Post-Drought Growth Recovery of Quercus Petraea and Quercus Robur in Europe. Sci. Total Environ. 2021, 784, 147222. [CrossRef] [PubMed]

79. Anderegg, W.R.L.; Schwalm, C.; Biondi, F.; Camarero, J.J.; Koch, G.; Litvak, M.; Ogle, K.; Shaw, J.D.; Shevliakova, E.; Williams, A.P. Pervasive Drought Legacies in Forest Ecosystems and Their Implications for Carbon Cycle Models. Science 2015, 349, 528-532. [CrossRef] [PubMed]

80. Huang, M.; Wang, X.; Keenan, T.F.; Piao, S. Drought Timing Influences the Legacy of Tree Growth Recovery. Glob. Chang. Biol. 2018, 24, 3546-3559. [CrossRef]

81. Sohn, J.A.; Saha, S.; Bauhus, J. Potential of Forest Thinning to Mitigate Drought Stress: A Meta-Analysis. For. Ecol. Manag. 2016, 380, 261-273. [CrossRef]

82. Fernandes, T.J.G.; Del Campo, A.D.; Herrera, R.; Molina, A.J. Simultaneous Assessment, through Sap Flow and Stable Isotopes, of Water Use Efficiency (WUE) in Thinned Pines Shows Improvement in Growth, Tree-Climate Sensitivity and WUE, but Not in WUEi. For. Ecol. Manag. 2016, 361, 298-308. [CrossRef]

83. Camarero, J.J.; Gazol, A.; Sangüesa-Barreda, G.; Oliva, J.; Vicente-Serrano, S.M. To Die or Not to Die: Early Warnings of Tree Dieback in Response to a Severe Drought. J. Ecol. 2015, 103, 44-57. [CrossRef]

84. Sánchez-Salguero, R.; Navarro-Cerrillo, R.M.; Camarero, J.J.; Fernández-Cancio, Á. Selective Drought-Induced Decline of Pine Species in Southeastern Spain. Clim. Change 2012, 113, 767-785. [CrossRef]

85. Sánchez-Salguero, R.; Linares, J.C.; Camarero, J.J.; Madrigal-González, J.; Hevia, A.; Sánchez-Miranda, Á.; Ballesteros-Cánovas, J.A.; Alfaro-Sánchez, R.; García-Cervigón, A.I.; Bigler, C. Disentangling the Effects of Competition and Climate on Individual Tree Growth: A Retrospective and Dynamic Approach in Scots Pine. For. Ecol. Manag. 2015, 358, 12-25. [CrossRef] 